\title{
PEMAHAMAN KONSEP ABSTRAK AJARAN AGAMA ISLAM PADA ANAK MELALUI PENDEKATAN SINEKTIK DAN ISYARAT ANALOGI DALAM ALQURAN
}

\author{
Alfauzan Amin \\ Institut Agama Islam Negeri (IAIN) Bengkulu \\ Jl. Raden Fatah, No 16 RT 07 Kel. Pagar Dewa Kota Bengkulu. \\ E-mail: alfauzan_amin@iainbengkulu.ac.id
}

\begin{abstract}
The Understanding of Abstract Concept of Islamic Teachings on Children Through a Synectic Approach and Analogic Cues in the Quran. The weakness of learning outcomes in understanding the concept of abstract has resulted in the spread of negative daily behavior. As an example of cheating behavior, disruptive behavior of other friends, dishonest behavior in the school cafeteria, truancy behavior, unsanitary and religious behavior, behaviors that can harm themselves and their environment. This paper seeks to analyze the message of the Quran that suggests that education applies the analogy method, which in reality has been realized as a synectic approach. The analysis of the discussion in this paper uses the perspective of various related theories of science; psychology, paedagogy, philosophy, and implications for related theories. As a result of the analysis, it can be concluded that the synectic approach as a form of implication step of the Quran cues about the use of analogies, is relevant to be used in learning the abstract aspect of religious teaching for children, especially for teenagers (junior high school).
\end{abstract}

Keywords: the concept of religious teachings; abstract material; synectic in the Quran.

\begin{abstract}
Abstrak: Pemahaman Konsep Abstrak Ajaran Agama Islam pada Anak Melalui Pendekatan Sinektik dan Isyarat Analogi dalam Alquran. Lemahnya hasil belajar aspek pemahaman konsep abstrak telah berdampak pada merebaknya prilaku sehari-hari yang negatif. Sebagai contoh prilaku mencontek, prilaku mengganggu teman lain, prilaku tidak jujur di kantin sekolah, prilaku membolos, prilaku yang tidak syar'i dan religius, prilaku yang dapat merugikan diri sendiri maupun lingkungannya. Tulisan ini berusaha menganalisis pesan Alquran yang mengisyaratkan agar pendidikan menerapkan metode analogi, yang pada kenyataannya sudah terealisasi sebagai pendekatan sinektik. Analisis pembahasan ini menggunakan sudut pandang berbagai teori bidang ilmu yang terkait; psikologi, paedagogy, philosofi, dan implikasi terhadap teori terkait. Sebagai hasil analisis diperoleh kesimpulan bahwa pendekatan sinektik sebagai bentuk langkah implikasi isyarat Alquran tentang penggunaan analogi, relevan digunakan dalam pembelajaran materi aspek abstrak ajaran agama pada anak, terutama anak usia remaja (sekolah menengah pertama).
\end{abstract}

Kata kunci: konsep ajaran agama; materi abstrak; sinektik dalam Alquran.

\section{Pendahuluan}

Materi pemahaman konsep abstrak, dalam hal ini aspek keimanan dan akhlak seringkali diserap oleh anak didik kurang maksimal atau hasil yang kurang memuaskan. Banyak fenomena sebagai dampak lemahnya hasil belajar aspek pemahaman konsep abstrak ini terhadap prilaku sehari-hari yang negatif. Sebagai contoh prilaku mencontek, prilaku mengganggu teman lain, prilaku tidak jujur di kantin sekolah, prilaku membolos, prilaku yang tidak syar'i dan religius, prilaku yang dapat merugikan diri sendiri maupun lingkungannya.
Hal tersebut disebabkan adanya kesalahan persepsi baik dari guru maupun siswa. Masih ada guru yang beranggapan bahwa mengajarkan pemahaman konsep ajaran agama yang bersifat abstrak adalah mudah. Ajaran agama yang bersifat abstrak cukup dijelaskan secara detil dengan ceramah dan tanya jawab. Namun kenyataannya masih banyak perilaku anak yang mencerminkan kurangnya penguasaan terhadap pemahaman konsep abstrak ajaran agama tersebut. Begitu pula siswa atau peserta didik menganggap bahwa pelajaran agama adalah materi mudah dengan alasan diamalkan dalam kehidupan sehari-hari. Tentu tidak sesederhana ini jika yang dimaksud 
istilah pemahaman adalah siswa betul-betul dianggap telah memiliki atau mengusai konsep pemahan abstrak ajaran agama dengan baik.

Namun demikian, bukan berarti materi tersebut tidak bisa diajarkan pada anak pada tingkat usia sekolah menengah pertama atau masa awal remaja dimana masa ini memerlukan penanganan khusus. Jika dirujuk Alquran, akan ditemukan ayat yang memberi petunjuk persoalan pembelajaran tersebut. Seberat atau seabstrak apapun materi, anak didik dengan kemampuan potensinya ${ }^{1}$ yang menonjol dibandingkan makhluk lain akan bisa menyerap dan menerima pemahaman ajaran tersebut dengan baik. Asalkan dengan pendekatan, model atau metode yang tepat. Pada tataran ini, pendidik dihadapkan tantangan menemukan solusi.

Alquran telah memberi isyarat model atau pendekatan yang bisa dikembangkan dalam pembelajaran. Sebagai contoh adalah konsep amtsal dalam Alquran. Ada redaksi penyampaian wahyu ajaran yang bersifat pemahaman abstrak dengan perumpamaan analogi atau metafora yang lebih kongkrit dengan tujuan mudah dipahami. Pendidik, pada tataran ini dihadapkan tantangan menemukan cara lebih teknis pada aplikasi pembelajaran di sekolah. Penulis mencoba menemukan bagaimana modifikasi teori baru tentang pendekatan pembelajaran materi konsep pemahaman abstrak sebagai analisis isyarat Alquran dengan teori-teori hasil temuan penelitian terdahulu. Agar lebih sistematis maka dapat dirumuskan sebagai berikut; (1) bagaimana karakteristik ajaran agama sebagai materi dalam mata pelajaran Pendidikan Agama Islam (PAI), sebagai materi yang bersifat konsep abstrak?, (2) apa yang dimaksud percepatan anak didik menerima ajaran agama bersifat abstrak sesuai dengan tingkat kematangan kemampuan penerimaannya?, (3) bagaimana isyarat Alquran mengajarkan materi-materi yang bersifat abstrak sehingga manusia mampu memahami sesuai dengan kehendak wahyu tanpa harus menunggu usia lebih dewasa terutama berkenaan dengan keimanan kepada yang gaib? (4) bagaimana teori yang bisa dibangun tentang pembelajaran

1 Jalaluddin, Teologi Pendidikan, (Jakarta: PT Raja Grafindo Persada, 2003), Cet. ke-3, h. 18. materi konsep abstrak kepada siswa usia awal remaja yang menarik dan cepat diserap dengan menggunakan perumpamaan atau sinektik?

Untuk menjawab problem tersebut sebagai solusi penulis menggali data berdasarkan kajian literatur, penelitian terdahulu, survey dan conten analisis. Pendekatan yang digunakan adalah; filosofis, psikologis, amtsal dalam Alquran dan sinektik. Pembahasan ini akan diurutkan sebagai berikut; ajaran aspek akidah sebagai materi konsep pemahaman abstrak, tinjauan filosofis dan psikologis anak didik, mengkongkritkan materi abstrak perspektif Alquran, pendekatan sinektik dalam pembelajaran materi abstrak, analisis teori percepatan pemahaman konsep abstrak melalui pendekatan sinektik sebagai oprasionalisasi isyarat Alquran tentang perumpamaan (amtsal).

\section{Aspek Akidah Akhlak sebagai sub-Materi PAI Konsep Pemahaman Abstrak}

Salah satu aspek lingkup materi PAI (Pendidikan Agama Islam) di Sekolah Menengah Pertama (SMP) adalah ajaran aspek akidah sebagai materi konsep pemahaman abstrak. Disebut materi konsep abstrak adalah karena materi tersebut dari segi obyek lebih bersifat tidak dapat dilihat, meskipun bisa dirasakan utamanya pada pengaruh kejiwaan atau ruhani dan spiritual yaitu keimanan yang murni seseorang. Keimanan yang murni adalah keimanan yang terbebas dari belenggu keyakinan adanya kekuatan lain selain Allah, dan belenggu hawa nafsu, dan godaan syaithan. Istilah "pembebasan" adalah usaha mendidik anak ke arah pemurnian akidah dan akhlak². Pada kurikulum pendidikan sekolah bisa digambarkan materi tersebut menyangkut; keimanan, sifat-sifat Allah, asma'ul husna dan cara meneladaninya dalam kehidupan, perilaku terpuji sebagai bentuk norma-norma yang bersumber dari keyakinan agama.

Istilah Pendidikan Agama Islam (PAI) dan pendidikan Islam sebenanya memiliki substansi yang berbeda, meskipun sering dipergunakan

${ }^{2}$ Lihat Alfauzan Amin, "Aktualisasi Kebebasan dalam Pendidikan Islam di Era Modern", Nuansa, Jurnal Studi Islam dan Kemasyarakatan, Vol 6 No 2, 2014. Diunduh 12 Mei 2016. http:// jurnal.pascasarjanaiainbengkulu.ac.id/index.php/nuansa/article/ view/21/0 
untuk peristilahan yang sama, misalnya ketika seseorang berbicara tentang pendidikan Islam ternyata isinya sebatas pada PAI, atau sebaliknya ketika seorang berbicara tentang PAI justru yang dibahas di dalamnya pendidikan Islam. Nama kegiatannya atau usaha-usaha dalam mendidikkan agama Islam itu disebut dengan PAI. ${ }^{3}$

Berdasarkan Standar Kompetensi Lulusan (SKL) pada pedidikan dasar dan menengah sebagaimana disebutkan dalam lampiran Permendikbud No. 54 tahun 2013. Dari SKL tersebut kemudian diturunkan ke Kompetensi Inti (KI) dan Kompetensi Dasar (KD) sebagaimana dijelaskan dalam Permendikbud No. 68 tahun 2013 tentang struktur kurikulum pada Sekolah Menengah Pertama/ MadrasahTsanawiyah sebagaimana tabel berikut ini. ${ }^{4}$

Tabel 1Contoh Standar Kompetensi dan Kompetensi Dasar

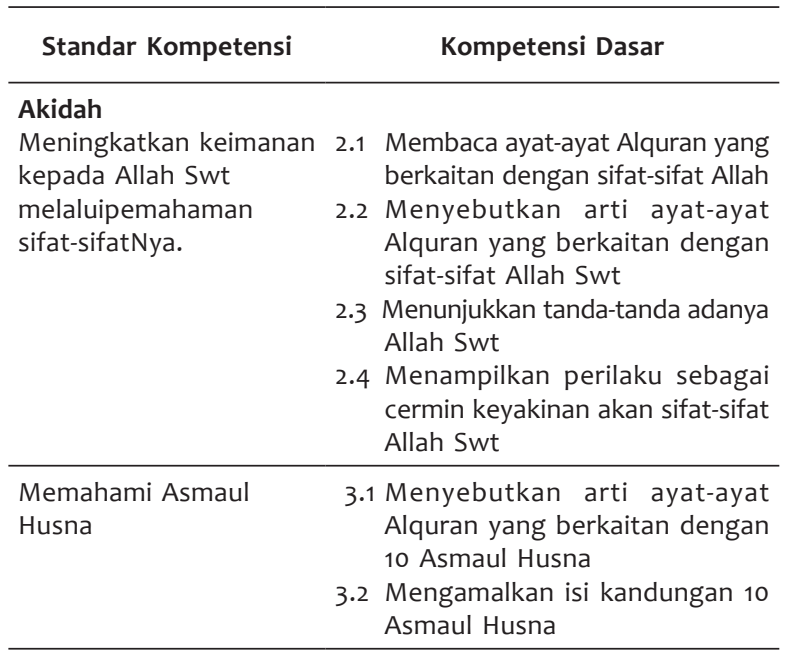

Pokok bahasan yang akan menjadi fokus dalam analisis ini sebagaimana telah dibatasi adalah materi yang termasuk pemahaman konsep abstrak. Dalam hal ini, Hindatulatifah ${ }^{5}$ mencontohkan konsep abstrak diantaranya adalah mengidentifikasi "sifat-sifat Allah" dengan menggunakan definisi.

${ }^{3}$ Muhaimin, Pengembangan Kurikulum Pendidikan Agama Islamdi Sekolah Madrasah dan Perguruan Tinggi, (Jakarta: Raja grafindo Persada, 2012), h. 6.

4 Lampiran Permendikbud No 68 Tahun 2013 tentang Struktur Kurikulum Pada SekolahMenenganh Pertamal Madrasah Stanawiyah, h. 5-6.

${ }^{5}$ Hidatulatifah, "Ranah-ranah Pembelajaran dan Implikasinya dalam Pendidikan Agama Islam”, Jurnal Pendidikan Agama Islam, Vol 8, No 1, 2008, h. 63.
Selanjutnya, istilah insight adalah suatu pemahaman atau penilaian yang beralasan mengenai reaksi-reaksi pengetahuan atau kecerdasan dan kemampuan yang dimiliki seseorang. ${ }^{6}$ Pemahaman berarti mengerti benar atau mengetahui benar. Pemahaman dapat juga diartikan menguasai sesuatu dengan pikiran. Karena itu, belajar berarti harus mengerti secara mental makna dan filosofinya, maksud dan implikasi serta aplikasi-aplikasinya, sehingga menyebabkan siswa memahami suatu situasi. Hal ini sangat penting bagi siswa yang belajar. Memahami maksudnya dan menangkap maknanya adalah tujuan akhir setiap mengajar. Pemahaman memiliki arti sangat mendasar yang meletakkan bagian-bagian belajar pada porsinya. Tanpa itu, maka pengetahuan, keterampilan, dan sikap tidak akan bermakna.

Berdasarkan uraian-uraian di atas dapat dipahami bahwa pemahaman merupakan kemampuan diri dalam mengerti atau mengetahui dengan benar terhadap sesuatu. Kemampuan memahami ini menjadi bagian penting dalam mengetahui atau mempelajari sesuatu. Belajar dengan mengharapkan sesuatu hasil yang baik, tidak cukup hanya sebatas kemampuan mengetahui. Seseorang memiliki pengetahuan atau mengetahui sesuatu, namun belum pasti ia memahaminya. Akan tetapi, seseorang yang memiliki pemahaman sudah tentu ia mengetahuinya. Jadi, pemahaman masih lebih tinggi tingkatannya daripada pengetahuan. Ini dapat diketahui bahwa pemahaman merupakan salah satu bentuk pernyataan hasil belajar. Pemahaman setingkat lebih tinggi dari pengetahuan atau ingatan. Materi agama terutama aspek akidah dan akhlak adalah tergolong memerlukan pemahaman tingkat tinggi. Materi ini termasuk materi sulit karena sifatnya yang abstrak, tetapi tetap harus dipahami anak. Untuk meningkatkan pemahaman tersebut diperlukan proses belajar yang baik dan benar diantaranya menyiapkan desain model pembelajaran yang inovatif dan kreatif. Dalam hal ini pembelajaran didesain berdasakan sintaks pendekatan sinektik yang digali dari isyarat Alquran. Dengan demikian, pemahman siswa akan dapat berkembang bila

\footnotetext{
${ }^{6}$ Hidatulatifah, "Ranah-ranah Pembelajaran..., h.7
} 
proses pembelajaran berlangsung dengan efektif dan efisien.

\section{Tinjauan Filosofis dan Psikologis Anak Didik}

Secara filosofis, anak adalah mahluk mulia dan harus diperlakukan secara mulia. Terutama perlakuanya dalam pendidikan. Karena manusia adalah makhluk educandum dan berbudaya, manusia membutuhkan proses pendidikan dan budaya. Sayangnya, usaha untuk menciptakan suatu sistem pendidikan yang dapat memindahkan nilai-nilai kebudayaan yang dikehendaki tersebut belum sepenuhnya dapat mencapai hasil yang maksimal serta memuaskan. Dengan kata lain, sistem pendidikan yang benar-benar mapan dapat diterima secara universal, bentuk nilainilai filosofis, serta serasi dengan fitrah manusia dan tatanan masyarakat masih belum ditemui7. Berbicara anak didik sebagai anak manusia yang memiliki sifat fitrah merupakan pembicaraan yang telah dibahas dalam Alquran. Dalam Alquran, manusia disebut dengan berbagai nama antara lain: al-basyar, al-insân, bani adam, al-ins, abdillâh dan khalifatullâh ${ }^{8}$. Manusia dinamai sesuai dengan sifat-sifat aslinya. Bisa mengarah positif dan negatif. Akan tetapi, manusia dibekali fitrah dan menjaga fitrah diantaranya dengan pendidikan yang baik.

Secara psikologis, periode perkembangan yang dimulai pada usia 12 tahun, yaitu yang lebih kurang sama dengan usia peserta didik SMP, merupakan 'period of formal operation'. Pada usia ini, yang berkembang pada peserta didik adalah kemampuan berfikir secara simbolis dan bisa memahami sesuatu secara bermakna (meaningfully) tanpa memerlukan objek yang konkrit atau bahkan objek yang visual. Peserta didik telah memahami hal-hal yang bersifat imajinatif. Implikasinya dalam pembelajaran adalah bahwa belajar akan bermakna kalau input (materi pelajaran) sesuai dengan minat dan bakat peserta didik. Pembelajaran akan berhasil kalau penyusun silabus dan guru mampu menyesuaikan tingkat

\footnotetext{
7 Jalaluddin, dkk, Filsafat Pendidikan Islam, Konsep dan Perkembangan Pemikirannya, (Jakarta: Raja Grafindo, 1994), h. 13.

8 Jalaluddin, Teologi Pendidikan,(Jakarta: Rajawali Press, 2000), h. 18
}

kesulitan dan variasi input dengan harapan serta karakteristik peserta didik sehingga motivasi belajar mereka berada pada tingkat maksimal.

\section{Unsur Sinektik dalam Alquran maupun Hadis tentang Penyampaian Ajaran Konsep Pemahaman Abstrak}

\section{Nabi Muhamad Saw Sebagai Pendidik}

Sebelum membahas sinektik sebagai pendekatan, penting ditinjau di sini bagaimana model pembelajaran zaman Rasulullah Saw yang berperan sebagai guru yang sempurna dan unsurunsur sinektik di dalamnya. Guru dalam proses belajar mengajar masih memegang peranan amat penting dan paling utama. Peranan guru masih belum bisa digantikan oleh alat elektronik yang canggih dan modern sekalipun. Banyak nilai-nilai manusiawi yang tidak dapat digantikan oleh alat elektronik seperti sikap, sistem nilai, fill, motivasi, habitasi, dan nilai-nilai lainnya seperti yang diharapkan dari tujuan pendidikan itu sendiri, karena pada dasarnya, tujuan dari pendidikan itu adalah untuk berkembangnya potensi peserta didik menjadi manusia berakhlak mulia, sehat, berilmu, cakap, kreatif, mandiri, demokrasi,dan bertanggung jawab9. Sementara tujuan yang hendak dicapai adalah terbentuknya kepribadian yang bulat dan utuh sebagai manusia individual dan sosial serta hamba Tuhan yang mengabdi diri kepada-Nya.

Agar tujuan utama dari pendidikan dalam proses belajar mengajar itu dapat tercapai, guru harus memiliki suatu cara atau pun model yang unik, menarik dan menyenangkan dalam menyampaikan pesan kepada peserta didik. Dengan model yang unik, menarik, dan menyenangkan maka pesan yang diberikan kepada siswa akan mudah diterima dan dicerna oleh siswa. Model yang digunakan dalam proses pembelajaran sangat berpengaruh terhadap penguasaan siswa terhadap pesan yang diberikan. Dengan kata lain, dalam proses pembelajaran jika model yang digunakan oleh guru tidak sesuai dengan kondisi maka hasil proses belajar mengajar pun tidak akan maksimal.

9 Hasbullah, Dasar-Dasarllmu Pendidikan, (Jakarta: Raja Wali Press,2005), h. 320. 
Pendekatan pembelajaran adalah bagian dari model pembelajaran. Model pembelajaran adalah bentuk pembelajaran yang tergambar dari awal sampai akhir yang disajikan secara khas oleh guru di kelas. Pendekatan adalah konsep dasar yang mewadahi, menginspirasi, menguatkan, dan melatari metode pembelajaran dengan cakupan teoretis tertentu. Model pada dasarnya berkaitan dengan rancangan yang dapat di gunakan untuk menerjemahkan sesuatu kedalam realitas, yang sifatnya lebih praktis. Adapun fungsinya sarana untuk mempermudah dan sebagai petunjuk bersifat perspektif dan petunjuk perencanaan untuk kegiatan pengelolaan ${ }^{10}$.

Adapun untuk menerapkan model tersebut dijabarkan ke dalam bentuk metode pembelajaran yang merupakan prosedur, urutan, langkahlangkah, dan cara yang digunakan guru dalam pencapaian tujuan pembelajaran. Maka dapat dikatakan bahwa metode pembelajaran merupakan jabaran dari pendekatan. Tidaklah berlebihan jika ada sebuah ungkapan "at-thariqah ahammu min al-mâddah", bahwa metode jauh lebih penting dibanding materi karena sebaik apapun tujuan pendidikan, jika tidak didukung oleh metode yang tepat, tujuan tersebut sangat sulit untuk dapat tercapai dengan baik."

Abuddin Nata menyimpulkan bahwa tujuan pendidikan adalah membina manusia agar menjadi khalifah Allah dimuka bumi. Akan tetapi, implementasi tujuan pendidikan tersebut harus disesuaikan dengan situasi dan kondisi suatu masyarakat, terutama peserta didik. Dengan demikian, implementasi tujuan pendidikan tersebut disesuaikan dengan bakat dan keahlian yang dimiliki oleh masing-masing peserta didik. ${ }^{12}$

Dengan demikian jelaslah bahwa agar tercapainya tujuan pendidikan sebagaimana yang diharapkan, diperlukan suatu strategi dan teknik yang sering dikenal dengan metode pembelajaran. Secara definitif, metode pembelajaran adalah suatu cara atau jalan yang ditempuh yang sesuai

10 Wina Sanjaya, Kurikulumdan Pembelajaran,Teori dan Praktik Pengembangan Kurikulum Tingkat Satuan Pendidikan (KTSP),(Jakarta: Kencana Prenada media Group; 2008), h. 82.

1 Qomari Anwar, Pendidikan Sebagai Karakter Bangsa, (Jakarta: UHAMKA Press, 2003), h. 43.

${ }^{12}$ Ibrahim, Inovasi Pendidikan, (Jakarta: Grasindo,1998), h. 89. dan serasi untuk menyajikan suatu hal sehingga akan tercapai suatu tujuan pembelajaran yang efektif dan efisien sesuai dengan yang diharapkan.

Sekalipun dibahas secara berpisah untuk masing-masing metode mengajar bukan berarti dalam praktik masing-masing metode tersebut berdiri sendiri-sendiri. Proses belajar mengajar yang baik adalah mempergunakan berbagai jenis metode mengajar secara bergantian atau saling bahu membahu satu dengan yang lainnya, karena masing-masing metode memiliki kekurangan dan kelebihan. Tugas guru adalah memilih berbagai metode yang tepat untuk menciptakan proses belajar mengajar.

Keberadaan Nabi Muhammad Saw sebagai seorang guru sekaligus materi pendidikannya yang merupakan tugas kerasulannya sudah dirancang dan di persiapkan Allah Swt. Sebagaimana firman Allah dalam Q.S. al-Jumu'ah [62]: 2.

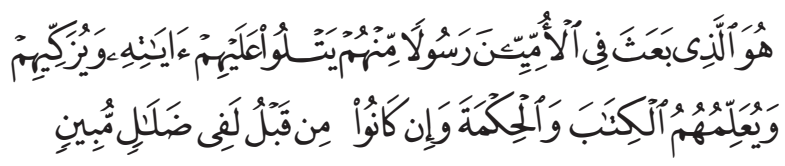

"Dialah yang mengutus kepada kaum yang buta huruf seorang Rasul di antara mereka, yang membacakan ayat-ayat-Nya kepada mereka, mensucikan mereka dan mengajarkan mereka Kitabdan hikmah (As-Sunnah). dan Sesungguhnya mereka sebelu "mnya benar-benar dalam kesesatan yang nyata".

Senada dengan ayat di atas firman Allah Swt dalam Q.S. Âli' Imrân [3]: 164:

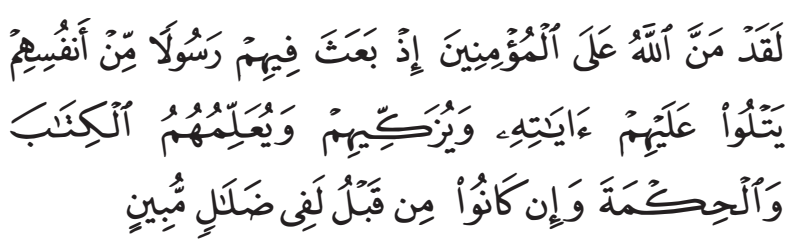

Sungguh Allah Telah memberi karunia kepada orang-orang yang beriman ketika Allah mengutus diantara mereka seorang Rasul dari golongan mereka sendiri, yang membacakan kepada mereka ayat-ayat Allah, membersihkan (jiwa) mereka, dan mengajarkan kepada mereka Al Kitab dan Al hikmah. dan Sesungguhnya sebelum(kedatangan $\mathrm{Nabi}$ ) itu, mereka adalah benar-benar dalam kesesatan yang nyata.

Kedua ayat di atas menjelaskan bahwa Nabi Muhammad Saw diutus oleh Allah Swt kepada umatnya untuk menanamkan ilmu sekaligus 
mensucikan jiwa mereka. "Mensucikan" berarti membersihkan dari sifat buruk yang merupakan sebagian besar masyarakat Makkah pada masa itu, dengan pengajaran dan pendidikan dengan memperhatikan situasi dan kondisi masyarakat pada waktu itu. ${ }^{13}$ Kedudukan beliau sebagai seorang pendidik (guru) dinyatakan dalam sabdanya: "Sesungguhnya Allah yang mengutusku sebagai seorang mu'allim dan pemberi kemudahan". Rasulullah Saw telah bersungguhsungguh dalam mendidik para sahabat dan generasi muslim sehingga mereka memiliki kesempurna akhlak, kesucian jiwa, dan karakter yang bersih. ${ }^{14}$

Rasulullah Saw adalah orang yang sangat konsisten dalam segala hal; beliau memerintahkan kebaikan kepada manusia. Atas sabdanya itu, beliau lah orang pertama yang melakukannya. Ketika beliau mencegah manusia untuk berbuat kejahatan, maka beliau adalah orang pertama yang menjauhinya. Ini adalah kesempurnaan akhlak beliau. Tidaklah mengherankan, karena akhlak beliau adalah Alquran.

Maka berkaitan dengan penjelasan tersebut, Nabi Muhammad Saw adalah ushwatun hasanah dan tentunya termasuk sebagai sosok guru yang telah nyata dan jelas serta melebihi atas semua sifat dan syarat seorang guru yang telah ditetapkan oleh para ahli pendidikan. An-Nahlawi, misalnya, menetapkan sepuluh sifat dan syarat bagi seorang guru, yaitu: memiliki sifat rabbani, menyempurnakan sifat rabbani dengan keikhlasan, mengajarkan ilmu dengan sabar, memiliki kejujuran, berpengetahuan luas di bidangnya, cerdik dan trampil menciptakan metode dalam pengajaran, tegas dan proporsional, memahami karakter dan kemampuan anak didik, peka terhadap fenomena kehidupan dan bersikap adil. ${ }^{16}$

Dengan demikian, penulis berpendapat bahwa Nabi Muhammad Saw sebagai ushwatun hasanah. Apabila dikaitkan dalam dunia pendidikan, beliau adalah sosok pendidik yang sempurna dalam segala aspek. Beliau adalah pendidik yang telah

\footnotetext{
${ }^{13}$ Alfiah, Hadis Tarbawiy (Pendidikan Islam Tinjauan Hadis Nabi), (Pekanbaru: Al-Mujtahadah Press; 2010), h. 83.

${ }^{14}$ Alfiah, Hadis Tarbawiy..., h. : 83.

${ }^{15}$ Fu'ad Asy Syalhub, Guruku Muhammad Saw, (Jakarta: Gema Insani; 2006), h. 11.

${ }^{16}$ Alfiah, Hadis Tarbawiy..., h. 85.
}

memberikan contoh atau model pembelajaran yang sangat akurat, dengan memperhatikan situasi dan kondisi. Dan, ada pun model yang telah beliau terapkan tersebut terbukti dalam dalam mendidik para sahabat dan umat manusia pada umumnya sehingga meraih keberhasilan untuk mencapai tujuan pendidikan.

Merujuk pada pola kependidikan dan keguruan Rasulullah Saw, dalam perspektif Islam, guru menjadi posisi kunci dalam membentuk kepribadian Muslim yang sejati. Adapun kajian tentang keberhasilan pendidikan dan pengajaran yang dilakukan oleh Nabi Muhammad Saw tersebut tidak saja dilakukan oleh umat Islam, tetapi hal di atas juga telah diungkapkan oleh selain Islam. Diantaranya oleh James E. Royster yang mengatakan bahwa Nabi Muhammad Saw tidak hanya menjadi guru bagi generasi masanya saja, tetapi juga pada masa sekarang dan menjadi seorang imaginary educator."

\section{Model-model Pembelajaran Nabi kepada Sahabat}

Sebenarnya, urgensi penggunaan model pembelajaran dalam dunia pendidikan telah dicontohkan oleh Nabi Muhammad Saw. Salah satunya adalah hadis berikut ini:

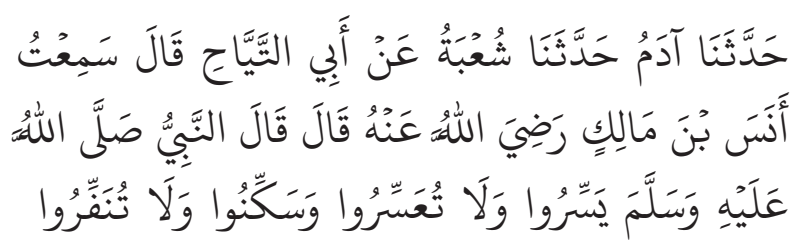
Mudahkanlah dan janganlah kamu mempersulit. Gembirakanlah dan janganlah kamu membuat mereka lari (H.R. Bukhari).

Dalam hadis di atas, secara tersirat Rasulullah Saw memerintahkan kepada kita untuk menyelenggarakan suatu kegiatan pembelajaran yang menyenangkan dan tidak sulit. Inilah sebenarnya salah satu metode yang cukup ideal dan bisa memberikan hasil yang optimal.

Berdasarkan beberapa ayat Alquran, hadis, dan penjelasan tersebut di atas, dapat dipahami bahwa ajaran Islam mengandung sumber inspirasi yang tidak akan pernah kering untuk mengembangkan ilmu pengetahuan, khususnya

\footnotetext{
${ }^{17}$ Alfiah, Hadis Tarbawiy..., h. 90.
} 
untuk mengembangkan model pembelajaran. Hal ini terbukti dengan begitu beragamnya ungkapan hadis nabi yang berkaitan langsung dengannya dalam mendidik para sahabat. Model pembelajaran yang dilakukan Nabi Muhammad Saw terhadap para sahabat adalah sebagai berikut.

\section{a. Analogi (kias)}

Sesekali dalam mengajar, Rasulullah Saw menggunakan analogi (perbandingan secara kias dengan bentuk yang sudah ada) terhadap suatu hukum atau ajaran yang kurang bisa dipahami dengan baik oleh sebagian sahabatnya, juga menjelaskan sebab-sebab akan sebuah hukum. ${ }^{18}$ Dengan penyepadanan dan analogi itu, para sahabatnya pun kemudian paham terhadap suatu hukum dan tujuan diterapkannya syari'at itu (maqâshid at-Tasyri'). Seperti yang beliau contohkan saat seorang perempuan dari suku Juhainah bertanya pada beliau, "Sesungguhnya ibuku telah bernazar untuk haji, tetapi sampai beliau meninggal belum sempat berhaji melaksanakan nazarnya itu. Apakah saya bisa berhaji (menggantikannya) atas nama beliau?" "Ya, bisa. Bukankah jika ibumu punya hutang dan belum sempat dilunasinya, lalu dia meninggal, kamu juga kan yang melunasi hutangnya?" jawab Rasul. "Ya, memang begitu," kata wanita itu lega (H.R. Bukhari).

\section{b. Tasybih dan Amtsal}

Syabah (tasybih) secara harfiah semakna dengan amtsâl (matsal) berarti serupa, sama, atau seperti. Dalam bahasa Arab, kata ini di gunakan untuk menyamakan sesuatu yang lain,seperti tergambar dalam ungkapan "anta mitslu asysyamsyi" (anda bagaikan matahari). ${ }^{19}$

Dalam banyak kesempatan saat mengajar, Rasulullah Saw juga menggunakan tasybih dan amtsal untuk menjelaskan suatu makna dari ajaran yang beliau sampaikan. Dalam penjelasannya, beliau menggunakan media benda yang banyak dilihat orang, atau yang mereka

18 Wina Sanjaya, Pengembangan Model Pembelajaran Metode Klinis Bagi Peningkatan Kemampuan Belajar Siswa, (Jakarta: Bulan Bintang, 2002), h. 77.

19 Kadar M. Yusuf, Tafsir Tarbawi, (Yogyakarta:Zanafa, 2001), h. 122. rasakan, atau yang mereka pegang. Hal ini sangat memudahkan pelajar untuk mendeskripsikan suatu masalah yang mungkin kurang jelas baginya. Cara ini umum digunakan oleh pengajarpengajar sastra, dan telah disepakati oleh mereka bahwa penggunaan tasybih dan amtsal memiliki pengaruh besar dan sangat membantu dalam menjelaskan sebuah arti yang samar dan kurang jelas. Dalam Alquran banyak sekali ayat yang menggunakan perumpamaan, dan tentu saja Nabi Saw banyak mengikuti metode Alquran ini dalam forum-forum pidato, orasi, dan cara mengajar beliau. ${ }^{20}$

Contoh sabda Rasulullah Saw berkenaan dengan tasybih dan amtsal ini sebagaimana disebutkan dalam shahih Muslim. Hadis dari Abu Musa Al-Asy'ari r.a, "Perumpamaan orang mukmin yang membaca Alquran itu laksana utrujah, rasanya lezat dan aromanya wangi. Sedangkan mukmin yang tidak membaca Alquran itu seperti kurma, rasanya enak tetapi tidak ada aromanya. Adapun orang munafik yang membaca Alquran itu seperti raihanah, aromanya harum, tapi rasanya pahit. Sedang orang munafik yang tidak baca Alquran, itu seperti hanzalah, pahit rasanya juga tidak ada aromanya." (HR. Bukhari dan Muslim). ${ }^{21}$ Atau sabda Rasulullah Saw yang lain, "Perumpamaan teman yang baik itu seperti pedagang minyak wangi, jika kamu tidak diberinya sedikit, maka kamu mendapat harum wanginya. Sedangkan teman yang buruk, itu seperti pandai besi, jika kamu tidak terkena percikan kecil apinya, maka kamu terkena asapnya." Dengan demikian perumpamaan seperti ini terkadang suatu permasalahan tampak lebih jelas dan lebih menancap kuat dalam hati dan ingatan para peserta didik dalam proses belajar mengajar.

\section{Pendekatan Sinektik dalam Pembelajaran Materi Abstrak}

Kata sinektik berasal dari bahasa Yunani yang berarti penggabungan unsur-unsur atau gagasangagasan yang berbeda-beda. Model Sinektik

${ }^{20}$ Wina Sanjaya, Pengembangan Kurikulum dan Pembelajaran, (Jakarta: Kencana- Perdana Media Group: 2005), h. 35.

${ }^{21}$ Ibnu Qayyim Al-Jauziyah, Buah Ilmu, terj. Fadhli Bahri, (Jakarat: Pustaka Azzam, 1999), h. 23. 
dapat dipahami sebagai strategi mempertemukan berbagai macam unsur, dengan menggunakan kiasan untuk memperoleh satu pandangan baru..$^{22}$ Model Pembelajaran Sinektik. Menurut Joyce, Weil, dan Calhoun ${ }^{23}$ semua model mengajar mengandung unsur model berikut: (a) orientasi model, (b) urutan kegiatan (syntax), (c) sistem sosial (social system), (d) prinsip reaksi (principle of reaction). Dalam hal ini model pembelajaran sinektik juga harus mencakup semua unsur tersebut.

\section{Orientasi}

Sinektik berarti penggabungan unsur-unsur atau gagasan-gagasan yang berbeda-beda yang tampaknya tidak relevan. Sinektik juga berarti strategi mempertemukan berbagai macam unsur, dengan menggunakan kiasan untuk memperoleh satu pandangan baru. Selanjutnya Model Sinektik yang ditemukan dan dirancang ini berorientasi meningkatkan kemampuan pemecahan masalah, ekspresi kreatif, empati dan wawasan dalam hubungan sosial.

\section{Urutan Kegiatan (syntax)}

Unsur kegiatan atau sintaksis merujuk pada rincian atau tahapan kegiatan model sehingga fase-fase kegiatan model tersebut teridentifikasi dengan jelas. Unsur kedua pembangun model sinektik ini adalah proses belajar mengajar sebagai struktur model pembelajaran. Ada dua strategi dari model pembelajaran sinektik, yaitu strategi pembelajaran untuk menciptakan sesuatu yang baru (creating something new) dan strategi pembelajaran untuk melazimkan terhadap sesuatu yang masih asing (making the strange familiar). Kedua strategi dari model pembelajaran sinektik dapat dilihat pada tabel berikut;

${ }^{22}$ William J. J. Gordon (9 September, 1919 - 30 JUNI 2003) adalah penemu dan psikolog. Dia diakui sebagai pencipta pendekatan pemecahan masalah yang disebut Synectics, yang dikembangkan saat bekerja di Invention Design Group of Arthur D. Little. Lihat https://en.wikipedia.org/wiki/ William_J._J._Gordon, 1980, h.168, diunduh 2 Mei 2015.

${ }^{23}$ Joyce, B., Weil, M. dan Calhoun, E, Models of Teaching, (Upper Seddle River New Jersey: Pearson Education, Inc, 2009), Eighth Edition, h. 135. a. Menciptakan sesuatu yang baru dengan metafora.

Tabel 2: Menciptakan Sesuatu yang Baru dengan Metafora

\begin{tabular}{|c|c|}
\hline $\begin{array}{l}\text { Tahap Pertama: } \\
\text { Mendeskripsikan } \\
\text { kondisi saat ini.Guru } \\
\text { meminta siswa untuk } \\
\text { mendeskripsikan situasi } \\
\text { suatu topik yang mereka } \\
\text { lihat saat itu. }\end{array}$ & $\begin{array}{l}\text { Tahap Kedua: Analogi } \\
\text { langsungSiswa } \\
\text { mengemukakan analogi } \\
\text { langsung, salah satu } \\
\text { diseleksinya dan selanjutnya } \\
\text { dikembangkan. }\end{array}$ \\
\hline $\begin{array}{l}\text { Tahap Ketiga: Analogi } \\
\text { personal. Para siswa } \\
\text { menganalogikan sesuatu } \\
\text { yang diseleksinya pada } \\
\text { fase kedua. }\end{array}$ & $\begin{array}{l}\text { Tahap Keempat:Konflik } \\
\text { kempaan/ padat. } \\
\text { Berdasarkan fase kedua } \\
\text { dan kedua dan ketiga, } \\
\text { para siswa mengemukakan } \\
\text { beberapa konflik dan dipilih } \\
\text { salah satunya. }\end{array}$ \\
\hline $\begin{array}{l}\text { Tahap Kelima:Analogi } \\
\text { langsung. Para siswa } \\
\text { mengembangkan dan } \\
\text { menyeleksi analogi } \\
\text { langsung lainnya } \\
\text { berdasarkan konflik tadi. }\end{array}$ & $\begin{array}{l}\text { Tahap Keenam:Meninjau } \\
\text { tugas yang sebenarnya. } \\
\text { Guru meminta para siswa } \\
\text { meninjau kembali tugas atau } \\
\text { masalah yang sebenarnya } \\
\text { dan menggunakan analogi } \\
\text { yang terakhir dan atau } \\
\text { masuk pada pengalaman } \\
\text { sinektik. }\end{array}$ \\
\hline
\end{tabular}

b. Mengakrabkan sesuatu yang asing melalui analogi-analogi yang sudah dikenal dengan baik.

Tabel 3: Mengakrabkan Sesuatu yang Asing melalui Analogi-analogi yang sudah dikenal dengan Baik

\begin{tabular}{|c|c|}
\hline $\begin{array}{l}\text { Tahap Pertama: Input } \\
\text { pada keadaan yang } \\
\text { sebenar-nya. Guru } \\
\text { menyajikan informasi } \\
\text { dengan topik baru. }\end{array}$ & $\begin{array}{l}\text { Tahap Kedua: Analogi } \\
\text { langsung. Guru mengusulkan } \\
\text { analogi langsung, dan siswa } \\
\text { diminta menjabarkannya. }\end{array}$ \\
\hline $\begin{array}{l}\text { Tahap ketiga: Analogi } \\
\text { personal } \\
\text { Guru meminta siswa } \\
\text { untuk membuat } \\
\text { analogi personal. }\end{array}$ & $\begin{array}{l}\text { Tahap Keempat: } \\
\text { Membandingkan. Para } \\
\text { siswa menjelaskan dan } \\
\text { menerangkan kesamaan } \\
\text { antara materi yang baru } \\
\text { dengan analogi langsung. }\end{array}$ \\
\hline $\begin{array}{l}\text { Tahap Kelima: } \\
\text { Menjelaskan } \\
\text { perbedaanPara siswa } \\
\text { menjelaskan analogi } \\
\text { yang tidak tepat. }\end{array}$ & $\begin{array}{l}\text { Tahap Keenam: Penjelajahan. } \\
\text { Para siswa menjelajahi } \\
\text { kembali kebenaran suatu } \\
\text { topik dengan batasan- } \\
\text { batasan mereka. }\end{array}$ \\
\hline \multicolumn{2}{|c|}{$\begin{array}{l}\text { Tahap Ketujuh: Memunculkan Analogi. Para siswa } \\
\text { memberikan analogi sendiri secara langsung dan } \\
\text { menjelajahi persamaan dan perbedaan. }\end{array}$} \\
\hline
\end{tabular}

Dalam model sinektik ini sangat menitik beratkan proses kreatif pada unsur metafor, yang menurut Joyce dan Weil mampu memperkenalkan jarak konseptual antara siswa dengan mata pelajaran yang menunjang motivasi dan imajinasi serta memecahkan masalah (solving the 
problem $)^{24}$. Menurut Waluyo ${ }^{25}$ ada tiga langkah dalam model sinektik ini, yaitu sebagai berikut;

1) Analogi Langsung (Direct Analogy)

Analogi langsung memerlukan penjajaran problem yang dihayati setelah membaca atau menonton sesuatu secara paralel. Pada analogi langsung dibedakan objek atau konsep sederhana dan tekanan pada pertentangan. Ada dua tahap analogi langsung, yaitu (1) menciptakan suatu yang baru, dan (2) menciptakan keanehan (kejutan). Untuk menciptakan keanehankeanehan unsur metafora dan analogi tetap sangat diperlukan.

2) Analogi personal (Personal Analogy)

Proses analogi langsung akan menghasilkan analogi personal, yang harus dicatat dan di analisis secara personal. Dalam hal ini siswa akan mengidentifikasi masalah yang dibahas. Siswa harus mencoba berpikir dan merasa, bagaimana seandainya siswa menjadi analog. Keterlibatan siswa secara individual dalam model sinektik melalui empat tahap analogi personal, yaitu (1) mendeskripsikan fakta, (2) mengidentifikasi fakta dengan kenyataan, (3) mengidentifikasi empati dengan sesuatu yang hidup (indera), dan (4) identifikasi empati dengan benda mati.

3) Konflik Kempaan/ Termampatkan (Compressed Conflict).

Analogi personal akan menghasilkan konflik kempaan, yang akan mepertahankan dua sudut pandangan yang berbeda. Dengan konflik kempaan, siswa dapat memahami apa yang telah dibaca atau dilihat merupakan suatu proses kegiatan mempertentangkan dari dua sudut pandangan yang berbeda. Pertentangan-pertentangan tersebut menurut Gordon memberikan pemahaman yang luas terhadap suatu objek yang baru. Besarnya jarak antara dua kerangka berfikir dapat meningkatkan proses kreatif pada diri siswa. Salah satu ciri kreativitas adalah mempunyai dorongan ingin tahu yang besar

${ }^{24}$ Herman J Waluyo, Drama Naskah, Pementasan dan Pengajarannya, (Surakarta: UNS Press,2001), h. 187.

${ }^{25}$ Herman J Waluyo, Drama Naskah..., h. 187 dan kemampuan mengembangkan suatu gagasan.

\section{Sistem Sosial}

Sistem sosial menandakan hubungan yang terjalin antara guru dan siswa, termasuk norma atau prinsip yang harus dianut dan dikembangkan untuk pelaksanaan model. Model ini menuntut agar antara guru dan siswa terdapat hubungan yang kooperatif di mana guru menjalankan dwifungsi sebagai pemrakarsa dan pengontrol aktivitas siswa pada setiap tahap. Selain itu guru menjadi fasilitator bagi kegiatan siswa dalam proses belajar mengajar.

\section{Prinsip Reaksi}

Prinsip reaksi bermakna sikap dan perilaku guru untuk menanggapi dan merespon bagaimana siswa memproses informasi, menggunakannya sesuai pertanyaan yang diajukan oleh guru. Tugas penting yang diemban guru pada tahap ini adalah menangkap kesiapan siswa menerima informasi baru dan aktivitas mental baru untuk dipahami dan diterapkan.

\section{Dampak-dampak Instruksional dan Pengiring}

Model sinektik memililki proses kreatif yang dapat dikomunikasikan dan dapat ditingkatkan melalui latihan langsung dengan mengembangkan teknik-teknik instructional khusus. Sinektik dapat diaplikasikan untuk pengembangan kekuatan kreatif umum dan pengembangan respons-respons kreatif pada beragam bidang masalah. Lingkungan sosial yang dapat mendorong kreatifitas dan menggunakan kohesi kelompok untuk dapat meningkatkan kekuatan yang memungkinkan para siswa memfungsikan dunia metaforis secara mandiri. Metode sinektik jelas dirancang untuk meningkatkan kreatifitas individu-individu dan kelompok. Meski demikian pembelajaran implisit dari model ini rata-rata cukup jelas. Sinektis tidak terbatas hanya pada stimulasi kreativitas seni tetapi dapat meningkatkan hampir semua usaha manusia dalam semua bidang kurikulum baik sain maupun seni.

Prosedur-prosedur sinektik membantu menciptakan komunitas kesetaraan di mana berfikir 
merupakan basis tunggal di dalamnya. Standar yang cukup menyenangkan seperti ini tentu akan memberikan dukungan kepada peserta didik yang sangat pemalu sekalipun. Prosedurprosedur sinektik dapat dihubungkan dengan diskusi guru—siswa dalam kelas dan materi-materi yang dibuat guru untuk siswa. Hasil aktifitas sinektik tidak selalu harus ditulis, tapi; dilisankan, aktifitas bermain peran, melukis, dan perubahanperubahan prilaku.

Sinektik yang digunakan untuk masalah sosial atau prilaku dapat diberitahukan prilaku situasional sebelum dan sesudah aktivitas sinektik serta mengamati perubahan-perubahan. Hal ini juga menarik dilakukan untuk memilih gaya-gaya ekspresif yang berbeda dengan topik awal, seperti meminta siswa melukis gambar tentang kerugian atau diskriminasi. Konsepnya abstrak tetapi gaya ekspresinya harus kongkrit.

Analogi-analogi dapat meningkatkan pembelajaran langsung dan jangka panjang (immediate and long-term learning), dan meningkatkan kesenangan siswa saat belajar. Untuk kajian yang mengeksplorasi keterampilan berfikir divergen yang spesifik dan umum, strategi-strategi peginduksian kreativitas umum (general creativityinducing strategies) dapat diterapkan dalam berbagai ranah, tetapi latihan khusus pada ranah tertentu (domain specific training) agaknya hanya bisa diterapkan untuk ranah-ranah lain yang lebih sempit. Sedangkan dengan analogi-analogi materi pelajaran sains dapat meningkatkan pembelajaran jangka panjang dan jangka pendek.

\section{Analisis Teori Percepatan Pemahaman Konsep Abstrak Melalui Pendekatan Sinektik sebagai Oprasionalisasi Isyarat Alquran dan Hadis tentang Perumpamaan (Amtsal)}

Salah satu tugas Guru Pendidikan Agama Islam (GPAI) adalah mentransinternalisasikan nilainilailslam kepada peserta didik melalui interaksi dalam proses pembelajaran yang dilakukannya. Keberhasilan guru dalam kegiatan belajar mengajar sangat tergantung dengan pendekatan, model dan metode atau teknik serta perangkat pembelajran lainya yang ditetapkan. Kegagalan pembelajaran seringkali karena kurang tepatnya guru dalam mendesain pembelajaran. Untuk materi agama terlebih aspek akidah (Iman kepada Allah, asmaul husna) dan akhlak (perilaku terpuji) sebagai modal dasar yang harus dibekalkan kepada siswa, masih terdapat guru yang menganggap materi ini mudah diajarkan. Namun pada kenyataannya masih banyak dalam pembelajarannya yang membuat siswa merasa malas, jenuh, dan tidak dapat membangkitkan motivasi atau minat siswa untuk mengikuti pembelajaran tersebut. Selain itu, siswa banyak yang kurang percaya diri untuk menunjukkan kemampuannya kepada orang lain. Salah satu syarat yang harus dipenuhi agar pembelajaran agama khususnya aspek akidah dan akhlak sesuai dengan tujuan, yaitu untuk mencapai kemampuan kreatif,pemilihan model pembelajaran harus diperhatikan dengan baik. Suatu pendekatan baru yang menarik dalam mengembangkan kreativitas telah dirancang oleh Gordon dengan nama sinektik sangat relevan digunakan dalam pembelajaran pemahaman konsep abstrak materi agama.

Mengatasi masalah tersebut yaitu masih adanya kesulitan siswa sekolah menengah dalam memahami konsep abstrak materi agama aspek akidah dan akhlak, maka perlu mendesain model pembelajaran yang betul-betul dapat menolong baik siswa maupun guru dalam proses pembelajaran. Seiring dengan masa perkembangan anak usia awal remaja (siswa SMP) dengan karakternya yang sudah mulai berkembang yaitu cara berfikirnya yang mulai kritis, dan tentunya tuntutan zaman sekarang yang sudah maju, harus mendapat respon secara positif. Salah satu respon adalah berfikir dan melakukan inovasi dalam pembelajaran, yaitu dengan mengembangkan desain pembelajaran PAI dengan pendekatan sinektik.

Pendekatan sinektik merupakan kegiatan yang membawa siswa belajar lebih menyenangkan. Sintaks yang ada di dalamnya menantang siswa selalu ingin berlatih berfikir kritis dan mengembangkan kreativitas berfikir. Hal ini disebabkan salah satu elemen penting pendekatan sinektik adalah cara belajar dengan bantuan berfikir dan aktivitas beranalogi atau metapora.

Sebab lain yang membuat menarik adalah ternyata istilah analogi adalah disebut juga 
"qiyas atau amtsal". Istilah amtsal sudah sangat populer dikenal sebagai salah satu cara Allah Swt memahamkan pesan-pesan-Nya kepada manusia yang terdapat dalam Alquran. Temuan Wiliam JJ Gordon tentang pendekatan sinektik ini adalah pengembangan yang aplikatif dari pesan yang tersirat dalam Alquran yang sudah sejak lama ada, jauh sebelum penemu pendekatan sinektik lahir. Hanya saja masih banyak praktisi pendidikan baik guru atau perancang pembelajaran agama Islam yang belum memanfaatkannya secara maksimal. Melalui kajian ini akan dicoba dan diuji bagaimana pembelajaran yang dirancang dengan sinektik ini dapat meningkatkan pemahaman ajaran agama yang abstrak.

Model pembelajaran berbasis pendekatan sinektik adalah pembelajaran yang didesain berdasarkan petunjuk Alquran dengan memanfaatkan langkah-langkah sinektik dengan berbantukan media gambar, media benda, cerita sebagai ilustrasi. Karena disain pembelajaran ini berbantukan beragam (multi) perangkat atau media tersebut dapat dituangkan dalam bentuk media yang menarik. Materi ajar yang disesuaikan dengan media ini secara teori akan membantu siswa.

Asumsinya berdasarkan hasil penelitian tentang pemanfaatan multimedia yang dikemukakan Rusman dkk, antara lain: (1) informasi atau materi pelajaran melalui teks dapat diingat lebih baik jika disertai dengan gambar (media) ${ }^{26}$. Hal ini dijelaskan dengan dual coding theory oleh Allan Paivio (1986). Menurut teori ini bahwa sistem kognisi manusia terdiri dari dua subsistem, yaitu sistem verbal, dan sistem gambar (visual) ${ }^{27}$; (2) Menurut Kadek Sukiyasa dkk. Berdasarkan hasil analisis penelitiannya, menunjukkan bahwa penyampaian materi sistem kelistrikan otomotif yang menggunakan media animasi dapat meningkatkan motivasi belajar siswa ${ }^{28}$; (3)

${ }^{26}$ Rusman, Model-model Multimedia Interaktif Berbasis Komputer, (P3MP: UPI, 2005), h. 34.

27 Allan Paivio, Mental Representations A Dual Coding Approach, (Oxford University Press, New York, Clarendon Press: Oxford, 1990), h. 53.

${ }^{28}$ Kadek Sukiyasa, "Pengaruh Media Animasi terhadap Hasil Belajardan Motivasi Belajar Siswa Materi Sistem Kelistrikan Otomotif", Jurnal Pendidikan Vokasi, Vol 3, Nomor 1, Februari 2013.
Menurut teori "quantum learning" peserta didik memiliki modalitas belajar yang berbeda,yang dibedakan menjadi 3 tipe, yaitu visual, auditif dan kinestetik. Keberagaman modalitas belajar ini diatasi dengan menggunakan perangkat bahan ajar. Sebab masing-masing peserta didik yang berbeda tipe belajarnya dapat diwakili oleh bahan ajar dengan variasi konsep pengembangan di dalamnya.

Kajian ini bertujuan untuk menghasilkan suatu desain pembelajaran baru, yakni pembelajaran PAI dengan pendekatan sinektik yang diadopsi dari Gordon, yang dirancang untuk memperkuat struktur kognitif siswa, sebagai acuan untuk mempelajari model perlakuan yang efektif dalam rangka meningkatkan kemampuan pemahaman konsep abstrak anak didik. Model sinektik Gordon sedemikian rupa dimodifikasi dan disesuaikan dengan kondisi yang ada serta diselaraskan dengan kebutuhan pembelajaran Pendidikan Agama Islam, sehingga diperoleh disain pembelajaran PAI dengan sinektik yang baru dan dapat mempercepat proses pemahaman siswa.

Oleh karena itu desain baru ini diharapkan akan menumbuhkan pemahaman baru pada materi yang bersifat pemahaman abstrak ${ }^{29}$. Untuk harapan tersebut dibutuhkan pendekatan model dan strategi yang betul-betul dipilih dengan penuh pertimbangan agar proses pembelajaran berlangsung efektif dan efisien. Salah satu pendekatan pembelajaran PAI yang dipandang dapat mencapai tujuan di atas adalah menggunakan model berpikir analogi atau qiyas dan amtsal yang sebenarnya cara ini pernah dicontohkan Nabi Muhammad Saw dalam pengajaran terhadap murid-muridnya yaitu para sahabat beliau ${ }^{30}$. Cara yang dicontohkan Nabi ini jugalah yaitu analogi atau qiyas ternyata yang menjadi elemen utama pendekatan sinektik yang dikenalkan oleh William J.J. Gordon. ${ }^{31}$

${ }^{29}$ Materi berupa pesan llahi yang tertuang dalam kitab suci Alquran. Lihat H.M. Suyudi, Pendidikan dalam Perspektif Alquran, (Yogyakarta: Mikraj, 2005), h.70.

${ }^{30}$ Irjus Indrawan, "Model Pembelajaran Nabi Muhammad Saw; Hiwar, Analogi, Tashbih dan Amtsal”, Jurnal al-Afkar, Vol.1 No.2 Oktober Th 2013.

${ }^{31}$ Bruce Jouce, at all, Models Of Teaching, Model-model Pengajaran, (Yogyakarta, Pustaka Pelajar, 2011), Cet. ke-II, 2011, h. 243.. 
Asumsi ketepatan penerapan sinektik untuk materi abstrak didasarkan pada pernyataan berikut;

Proses sinektik dikembangkan dari beberapa asumsi salah satu nya adalah bahwa analisis terhadap proses irasional dan emosional tertentu dapat membantu individu dan kelompok untuk meningkatkan kreativitas mereka dengan menggunakan irasionalitas secara konstruktif. Aspek-aspek irasional dapat dipahami dan dikontrol sacara sadar. Pencapaian kontrol ini melalui penggunaan metafora dan analogi secara seksama, merupakan obyek sinektik ${ }^{32}$.

Pendapat di atas menguatkan bahwa konsep yang abstrak (aspek irasional) dapat dipahami dengan mudah melalui sinektik. Suhudi juga berpendapat bahwa; "analogi atau amṡal dapat digunakan untuk memahamkan sesuatu yang abstrak, sehingga dapat diindra agar mudah diterima, karena makna yang diproses oleh amtsal belum terlintas oleh pikiran kecuali setelah diilustrasikan". Ayat Alquran Q.S. al-Baqarah [2]: 264 berikut ini bisa dijadikan dasar;

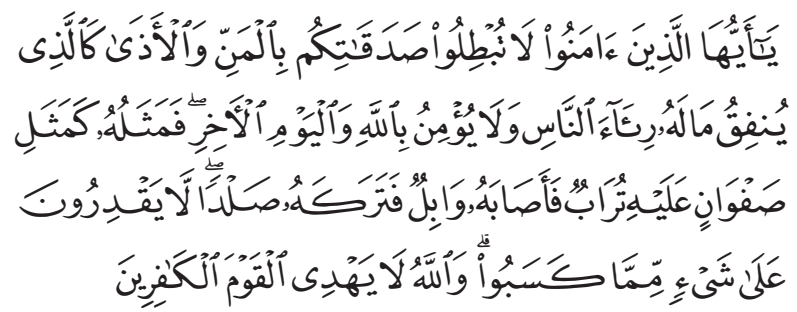

Hai orang-orang yang beriman, janganlah kamu menghilangkan (pahala) sedekahmu dengan menyebut-nyebutnya dan menyakiti (perasaan si penerima), seperti orang yang menafkahkan hartanya karena riya kepada manusia dan Dia tidak beriman kepada Allah dan hari kemudian. Maka perumpamaan orang itu seperti batu licin yang di atasnya ada tanah, kemudian batu itu ditimpa hujan lebat, lalu menjadilah Dia bersih (tidak bertanah). mereka tidak menguasai sesuatupun dari apa yang mereka usahakan; dan Allah tidak memberi petunjuk kepada orang-orang yang kafir.

Perumpamaan yang diungkapkan dalam ayat di atas adalah cara Allah memahamkan kepada hamba-Nya agar cepat menyerap pesan ya $g$ dimaksud di dalamnya. Inilah amtsal sebagai dasar dikembangkanya pendekatan sinektik

${ }^{32}$ Bruce Joice, Models...., h. 253. untuk menjelaskan materi-materi agama tentang konsep abstrak. Namun amtsal dalam implementasinya sebagai sarana percepatan proses pembelajaran membutuhkan ilustrasi. Maka sebagai implikasi nya adalah penerapan media tertentu sebagai alat bantu percepatan pemahaman. Media tersebut bisa berupa media benda, media gambar, atau media cerita. Inilah karakter pembelajaran dengan amtsal atau sinektik yang bermakna pertalian.

Sinektik adalah proses menemukan pertalian dari segala hal yang tidak diketahui sebelumnya atau bahkan bertentangan. la meliputi berbagai upaya mengkoordinasikan segala sesuatu ke dalam suatu struktur baru agar ditemukan hubungan antara satu dengan yang lainnya. Dengan kata lain berpikir sinektik adalah proses identifikasi segala hal yang tidak diketahui sebelumnya untuk dicari jalan keluarnya, dibuat dugaan-dugaan atau hipotesa.

Dalam tataran praktis dan aplikatif, aktifitas sinektik bersifat metaporik dengan menemukan analogi-analogi yang dengan sendirinya kreatifitas menjadi suatu yang disadari. Metapora-metapora membentuk hubungan persamaan serta membedakan obyek atau ide yang satu dengan yang lainnya. Model pembelajaran seperti ini mengajak siswa untuk menjiwai dan menghayati sejumlah pengetahuan ke dalam ranah afeksi sehingga terjadi proses persepsi dan penghayatan yang mendorong siswa memaknai setiap pengalaman pembelajaran akidahnya. Pemahaman konsep akidah yang notabene bersifat abstrak sebagai hasil belajar akhirnya tercapai. Percepatan terjadi karena tidak perlu menunggu usia lebih dewasa untuk memahami makna konsep akidah yang benar dan mampu mewarnai sikap prilaku dalam kehidupan sehari-hari. Inilah sebagai gambaran dari desain teori pembelajaran sinektik.

Demikianlah ahlak mulia akan terwujud pada diri seseorang karena memiliki akidah dan syariah yang benar. Seorang Muslim yang memiliki akidah atau iman yang benar pasti akan terwujud pada sikap dan perilaku sehari-hari yang didasari oleh imannya. Sebagai contoh, orang yang memiliki iman yang benar kepada Allah ia akan selalu mengikuti seluruh perintah Allah dan menjauhi seluruh larangan-larangan-Nya. Dengan demikian, 
ia akan selalu berbuat yang baik dan menjauhi hal-hal yang dilarang (buruk). Iman kepada yang lain (malaikat, kitab, dan seterusnya) akan menjadikan sikap dan perilakunya terarah dan terkendali, sehingga akan mewujudkan akhlak mulia. Hal yang sama juga terjadi dalam hal pelaksanaan syariah. Semua ketentuan syariat Islam bermuara pada terwujudnya akhlak mulia. Seorang yang melaksanakan salat yang sesuai dengan ketentuan yang berlaku, misalnya, pastilah akan membawanya untuk selalu berbuat yang benar dan terhindar dari perbuatan keji dan mungkar.

\section{Penutup}

Berdasarkan dari pembahasan di atas dapat ditarik kesimpulan sebagai berikut:

Pertama; Kajian karakteristik ajaran agama sebagai materi dalam mata pelajaran Pendidikan Agama Islam (PAI), diketahui terdapat materi yang bersifat konsep abstrak terutama berkenaan dengan keimanan kepada yang gaib. Materi tergolong sulit dipahami siswa. Pendidik perlu berkreasi dan inovasi dengan berpedoman pada petunjuk Alquran.

Kedua; Anak didik dapat menerima ajaran agama bersifat abstrak sekalipun, sesuai dengan tingkat kematangan kemampuan penerimaannya tanpa harus menunggu usia lebih dewasa. Hal inilah yang penulis sebut denggan percepatan. Anak didik secara filosofi dan psikologis lahir dengan sejumlah potensi yang menonjol sebagai wadah untuk menerima konsep-konsep pengembangan ajaran mental dan spiritual. Secara psikologis anak usia awal remaja (usia sekolah menengah) sudah mulai mampu berkfikir kritis baik segi intelegensi maupun intuisi.

Ketiga; Alquran di dalamnya terdapat petunjuk atau isyarat bagaimana mengajarkan materi-materi yang bersifat abstrak sehingga umat tetap mampu memahami sesuai dengan kehendak wahyu. Misalnya surat al-Baqarah [2] ayat 24, yang mengisyaratkan bagaimana Allah Swt menyampaikan (wahyu) materi ajaran dengan perumpamaan (amtsal). Masih banyak ayat-ayat lain yang menggunakan gaya serupa. Begitu pula Nabi Muhammad Saw dalam beberapa hadis menggambarkan betapa beliau menjadi guru yang agung tercermin dalam proses pembelajaranya menggunakan penjelasan melalui perumpamaan yang yang jelas.

Keempat; mengajarkan materi konsep abstrak kepada siswa usia awal remaja sangat menarik dan cepat diserap dengan menggunakan perumpamaan. Dalam istilah pendekatan pembelajaran yang sering dikenal dengan istilah sinektik, yaitu strategi mempertemukan berbagai macam unsur, dengan menggunakan kiasan untuk memperoleh satu pandangan baru. Dengan kias ditambah ilustrasi sebagaimana pesan yang diisyaratkan dalam Alquran, materi abstrak bisa menjadi kongkrit dalam pikiran anak didik. Semakin kongkrit materi disampaikan kepada anak didik maka akan semakin mudah dan cepat diserap dalam memahami makna yang terkandung. Penggunaan media alat bantu adalah implikasi dari penerapan teori desain pembelajaran ini sebagai ilustrasi.

\section{Pustaka Acuan}

Alfiah, Hadis Tarbawiy (Pendidikan Islam Tinjauan Hadis Nabi), Pekanbaru: Al-Mujtahadah Press, 2010.

Amin, Alfauzan, "Aktualisasi Kebebasan dalam Pendidikan Islam di Era Modern", Nuansa, Jurnal Studi Islam dan Kemasyarakatan, Vol 6 No 2, 2014. Diunduh 12 Mei 2016.http:// jurnal.pascasarjanaiainbengkulu.ac.id/index. php/nuansa/article/view/21/0

Anwar, Qomari, Pendidikan Sebagai Karakter Bangsa, Jakarta: UHAMKA Press, 2003.

Bruce Jouce, at al, Models Of Teaching, Model-model Pengajaran, Yogyakarta: Pustaka Pelajar, Cet. ke- II, 2011.

Fu'ad Asy Syalhub,Guruku Muhammad Saw, Jakarta: Gema Insani, 2006.

Gulo, Strategi Belajar Mengajar, Jakarta: Grasindo, 2002.

Hasbullah, Dasar-Dasar Ilmu Pendidikan, Jakarta: Raja Wali Press, 2005.

Hidatulatifah, "Ranah-ranah Pembelajaran dan Implikasinya dalam Pendidikan Agama Islam", Jurnal Pendidikan Agama Islam, Vol 8, No 1, 2008. Ibrahim, Inovasi Pendidikan, Jakarta, Grasindo,1998. Irdus, Indrawan, "Model Pembelajaran Nabi Muhammad Saw; Hiwar, Analogi, Tashbih dan Amtsal", Jurnal al-Afkar, Vol.1 No.2 Oktober Th 2013. 
Jalaluddin, dkk, Filsafat Pendidikan Islam, Konsep dan Perkembangan Pemikirannya, Jakarta: Raja Grafindo, 1994.

Joyce, B., Weil, M. dan Calhoun, E, Models of Teaching, Upper Seddle River New Jersey: Pearson Education, Inc, Eighth Edition, 2009.

Kadar, M. Yusuf, Tafsir Tarbawi, Yogyakarta: Zanafa, 2001.

Kadek Sukiyasa, "Pengaruh Media Animasi terhadap Hasil Belajar dan Motivasi Belajar Siswa Materi Sistem Kelistrikan Otomotif", Jurnal Pendidikan Vokasi, Vol 3, Nomor 1, Februari 2013.

Koestoer Partowisastro, Dinamika dalam Psikologi Pendidikan, (Jilid I). Jakarta: Erlangga, 1983. Muhaimin, Pengembangan Kurikulum Pendidikan Agama Islamdi Sekolah Madrasah dan Perguruan Tinggi, Jakarta: Raja grafindo Persada, 2012.

Mujib, Abdul dan Jusuf Mudzakir, Ilmu Pendidikan Islam, Jakarta: Kencana, 2010.

Muzayyin Arifin, Pendidikan Islam dan Arus Dinamika Masyarakat, Jakarta:Golden Trayon Press, tt.
Paivio, Allan, Mental Representations A Dual Coding Approach, Oxford University Press, New York: Clarendon Press, Oxford, 1990.

Qayyim, Ibnu,Al-Jauziyah,Buahllmu,Penerjemah FadhliBahri,PustakaAzzam, Jakarta, 1999.

Ramayulis, IImu Pendidikan Islam, Jakarta: Kalam Mulia, 1994

Rusman, Model-model Multimedia Interaktif Berbasis Komputer, P3MP: UPI, 2005.

Sanjaya, Wina, Pengembangan Kurikulum dan Pembelajaran, Jakarta: Kencana- Perdana Media Group: 2005.

, Pengembangan Model Pembelajaran Metode Klinis Bagi Peningkatan Kemampuan Belajar Siswa, Jakarta: Bulan Bintang, 2002. , Kurikulum dan Pembelajaran, Teori dan Praktik Pengembangan Kurikulum Tingkat Satuan Pendidikan (KTSP), Jakarta: Kencana Prenada media Group; 2008.

Suyudi, H.M. Pendidikan dalam Perspektif Alquran, Yogyakarta, Mikraj, 2005.

William J. J. Gordon (https://en.wikipedia.org/ wiki/ William_J._J._Gordon, diunduh 2 Mei 2015. 